\title{
Effects of LH-RH agonist or LH-RH immunoneutralization on pituitary and ovarian LH-RH receptors in female rats
}

\author{
Rachel M. Popkin, H. M. Fraser and R. G. Gosden* \\ M.R.C. Reproductive Biology Unit, Centre for Reproductive Biology, 37 Chalmers Street, \\ Edinburgh EH3 $9 E \mathrm{~W}$, and ${ }^{*}$ Department of Physiology, University of Edinburgh, \\ Edinburgh EH8 $9 A G, U . K$.
}

\begin{abstract}
Summary. Hyperstimulation of pituitary function using daily injections of 50,500 or $5000 \mathrm{ng}$ LH-RH agonist for 3 weeks or hypostimulation by immunoneutralization of endogenous $\mathrm{LH}-\mathrm{RH}$ led to disrupted oestrous cycles and profound changes in ovarian morphology. Despite this, the number of pituitary and ovarian LH-RH receptors remained within the range found in normally cyclic animals. Autoradiography confirmed that specific binding was located in theca, granulosa and luteal cells.

These results suggest that autoregulation of pituitary and ovarian LH-RH receptors is not of primary importance in the cyclic female rat.
\end{abstract}

\section{Introduction}

Receptors for luteinizing hormone-releasing hormone (LH-RH) are present in the anterior pituitary gland and ovary of the rat. Pituitary LH-RH receptor numbers change markedly under different physiological conditions, for example, during the oestrous cycle (Park, Saxena \& Gandy, 1976; Savoy-Moore, Schwartz, Duncan \& Marshall, 1980; Clayton, Solano, Garcia-Vela, Dufau \& Catt, 1980; Marian, Cooper \& Conn, 1981; Meidan \& Koch, 1981; Reeves, Tarnavsky \& Platt, 1982), lactation (Clayton et al., 1980; Reeves et al., 1982) and after ovariectomy (Reeves et al., 1982). These changes are thought to reflect exposure of the pituitary to hypothalamic LH-RH and may be important in mediating changes in pituitary responsiveness. In contrast, no marked changes in ovarian LH-RH receptors have been observed in cyclic or lactating rats (Pieper, Richards \& Marshall, 1981; Reeves et al., 1982). However, LH-RH can act directly on the ovary to influence steroidogenesis (Hsueh \& Erickson, 1979; Clark, 1982; Popkin, Fraser \& Jonassen, 1983), oocyte maturation (Ekholm, Hillensjö \& Isaksson, 1981) and ovulation (Corbin \& Bex, 1981; Ekholm et al., 1981).

In the present investigation we have exposed the pituitary and ovary to very high or low levels of LH-RH, and therefore to variation in gonadotrophin stimulation, by treating cyclic female rats with daily injections of an LH-RH agonist or immunoneutralization by LH-RH antibodies. LHRH receptor numbers were examined under these conditions which produced marked changes in ovarian morphology. In addition the distribution of labelled LH-RH in the ovary was investigated using autoradiography. 


\section{Materials and Methods}

Animals. Adult female Sprague-Dawley rats (60-80 days old) were housed under conventional conditions with lights on between 05:00 and 19:00 h and were exhibiting regular oestrous cycles. Vaginal smears were taken daily to assess vaginal cytology before and during treatment.

Chronic treatment with $L H-R H$ agonist and $L H-R H$ antiserum. Animals were divided into 6 groups of 8 . Treatment commenced at random stages of the cycle. Rats in Groups 1-3 were injected subcutaneously at $09: 00 \mathrm{~h}$ daily for 3 weeks with 50, 500 or $5000 \mathrm{ng}$ LH-RH agonist (D-Ser But ${ }^{6}$ des Gly ${ }^{10}$ LH-RH ethylamide; Hoechst AG, Frankfurt, West Germany) dissolved in $1 \%$ gelatin and $0.9 \%(\mathrm{w} / \mathrm{v}) \mathrm{NaCl}$. Rats in Group 4 were injected with $0.5 \mathrm{ml}$ antiserum to LH-RH raised in sheep (Clayton, Popkin \& Fraser, 1982) once every 3 days. The first antiserum injection was given i.v. and the remainder s.c. In rats at $12: 00 \mathrm{~h}$ on the day of pro-oestrus, injection of $0.5 \mathrm{ml} \mathrm{LH}-\mathrm{RH}$ antiserum prevented the LH surge and ovulation (R. M. Popkin \& H. M. Fraser, unpublished observations). Control rats received either vehicle alone or antiserum to human serum albumin (HSA) and were killed on the day of dioestrus (Group 6) or pro-oestrus (Group 5) at 12:00 h. Since no difference was found between HSA- and vehicle-treated rats the results were pooled.

At $24 \mathrm{~h}$ after the final injection (or on the day of pro-oestrus or dioestrus for controls in Groups 5 and 6), rats were anaesthetized with $\mathrm{CO}_{2}$ generated from solid $\mathrm{CO}_{2}$. Blood was collected by decapitation and after centrifugation the serum was stored at $-20^{\circ} \mathrm{C}$ before hormone assay. The adenohypophysis was rapidly removed and homogenized immediately in $10 \mathrm{mM}$-Tris- $\mathrm{HCl} \mathrm{pH} 7 \cdot 4$ for LH-RH agonist binding assay, an aliquot of the homogenate being stored at $-20^{\circ} \mathrm{C}$ for gonadotrophin content and protein determination. The ovaries and distended uteri were weighed. The right ovary was taken for immediate binding assay. The left ovary was placed in Bouin's fluid and after fixation embedded in paraffin wax. Serial sections were cut at $5 \mu \mathrm{m}$ and stained with haematoxylin-eosin.

Radioimmunoassays. Serum concentrations and pituitary content of LH and FSH were measured as previously described (Fraser \& Sandow, 1977; de Jong \& Sharpe, 1977) and the results expressed in terms of the appropriate NIAMDD preparation (RP-1). Oestradiol-17 $\beta$ and progesterone were determined as described by Backstrom, McNeilly, Leask \& Baird (1982) and Scaramuzzi, Corker, Young \& Baird (1975) respectively. All samples were run in single assays. All samples for individual hormones were measured in single assays with a within-assay variation (as percentage coefficient of variation) of $9 \%, 11 \%, 7 \%$ and $8 \%$ and sensitivities of $6 \mathrm{ng} / \mathrm{ml}, 50 \mathrm{ng} / \mathrm{ml}$, $0.2 \mathrm{ng} / \mathrm{ml}$ and $10 \mathrm{pg} / \mathrm{ml}$ for $\mathrm{LH}, \mathrm{FSH}$, progesterone and oestradiol respectively.

LH-RH receptor assay. LH-RH receptor concentrations from individual pituitaries were assessed using previously described methods (Clayton et al., 1982; Fraser, Popkin, McNeilly \& Sharpe, 1982). The right ovary was subjected to the same procedure, i.e. homogenization in Tris$\mathrm{HCl}(10 \mathrm{~mm}, \mathrm{pH} 7 \cdot 4)$ and the homogenate was filtered through nylon gauze. The $50 \mu$ aliquants were used in the binding assay which was carried out on ice for $2 \mathrm{~h}$. Protein determination was performed by the method of Lowry, Rosebrough, Farr \& Randall (1951) using BSA as the standard. Pituitary protein content did not vary between treatment groups so the results for pituitary binding are expressed as fmol bound/pituitary. Since ovarian protein content did vary between groups, ovarian binding is expressed as fmol bound/mg protein.

Autoradiography. Two pro-oestrous rats weighing $250 \mathrm{~g}$ were anaesthetized at $12: 00 \mathrm{~h}$ with ethyl carbamate $(1.75 \mathrm{~g} / \mathrm{kg}$ body wt, injected i.p. as a $25 \%$ solution (w/v) BDH Ltd, Poole, Dorset, U.K.) and the right atrium of each was cannulated. Each rat was given a $1-\mathrm{ml}$ injection of ${ }^{125} \mathrm{I}$-labelled LH-RH agonist $\left(2.9 \times 10^{7}\right.$ c.p.m. $)$ alone or with a 100 -fold excess of unlabelled hormone at $\mathrm{pH} 7$ into the atrial cannula over a period of $2 \mathrm{~min}$. The animals were killed $30 \mathrm{~min}$ later by perfusion with $30 \mathrm{ml}$ heparinized saline and this was immediately followed by $20 \mathrm{ml} \mathrm{10 \%}$ neutral buffered formal-saline solution. The ovaries and pituitary glands were dissected out and immersed in this fixative solution and were counted in a gamma spectrometer. In the animal injected with ${ }^{125} \mathrm{I}^{-}$ labelled LH-RH agonist ovary count was 2100 c.p.m./mg, the pituitary 3200 c.p.m./mg and the 
blood count 270000 c.p.m./ml. The corresponding values for the rat injected with ${ }^{125}$ I-labelled LHRH agonist and unlabelled hormone were 100 c.p.m./mg and 350 and 220000 c.p.m./ml. After fixation for $4 \mathrm{~h}$ the tissues were transferred to $2 \%$ glutaraldehyde (TAAB, Reading, Berks, U.K.) in $0.01 \mathrm{M}$-Hepes buffer ( $\mathrm{pH} \mathrm{7.2)}$ for further fixation overnight at $4^{\circ} \mathrm{C}$. The tissues were then washed with distilled water, snap-frozen and sectioned at $12 \mu \mathrm{m}$ with a cryostat. The sections were mounted on acid-cleaned slides and coated with liquid nuclear emulsion (K5, Ilford Ltd, Basildon, Essex, U.K.). Additional tissues from untreated rats were prepared similarly to control for chemographic effects (high background activity and latent image fading). The slides were exposed in light-proof boxes at $4^{\circ} \mathrm{C}$ for 33 days. They were then developed and fixed (D19 developer and Kodafix, Kodak Ltd, Liverpool, U.K.) and stained with haemalum and eosin. Each slide was examined microscopically at high power $(\times 1000)$ under oil-immersion and with bright-field and dark-ground illumination.

Statistical analysis. Differences between dioestrous control and treated groups were analysed by Student's $t$ tests.

\section{Results}

\section{Ovarian morphology}

Ovarian function was dramatically altered by long-term LH-RH agonist and LH-RH antibody treatment. Ovarian weight was increased after treatment with 500 or $50 \mathrm{ng} \mathrm{LH-RH}$ agonist and decreased after LH-RH antibody treatment (Table 1). The morphology was assessed by comparing the contribution to the overall mass of the ovaries by the various constituent structures (follicles, corpora lutea and stroma) on a scale $0-3$ using coded slides from each group of animals. The greatest degree of contrast was found between animals in Group 3 (Pl. 1, Fig. 3) and the controls in Groups 5 and 6 at pro-oestrus and dioestrus (Pl. 1, Fig. 1). Growing types of follicles from unilaminar to Graafian sizes were notably lacking in Group 3 rats, and in one animal were virtually absent. These types were also less abundant in the treated animals in Groups 1 and 2, although to a smaller degree. The numbers of primordial (non-growing) follicles were counted in one approximately equatorial section of each ovary but were unaffected by the treatments (range of means 11-15 in Groups 1, 2 and 3). Small and medium-sized follicles appeared to be growing normally whereas Graafian follicles were frequently seen to be undergoing premature luteinization

Table 1. Effect of treatment with LH-RH agonist or LH-RH antiserum for 3 weeks on serum LH, FSH, progesterone and oestradiol concentrations, pituitary content of LH and FSH and uterine and ovarian weight

\begin{tabular}{|c|c|c|c|c|c|c|c|c|c|}
\hline \multirow[b]{2}{*}{ Group } & \multirow[b]{2}{*}{ Treatment } & \multicolumn{2}{|c|}{ Serum } & \multicolumn{2}{|c|}{ Pituitary } & \multicolumn{2}{|c|}{ Serum } & \multirow{2}{*}{$\begin{array}{l}\text { Paired } \\
\text { ovarian } \\
\text { wt }(\mathrm{mg})\end{array}$} & \multirow[b]{2}{*}{$\begin{array}{l}\text { Uterine } \\
\text { wt (mg) }\end{array}$} \\
\hline & & $\begin{array}{c}\text { FSH } \\
(\mathrm{ng} / \mathrm{ml})\end{array}$ & $\underset{(\mathrm{ng} / \mathrm{ml})}{\mathbf{L H}}$ & $\begin{array}{l}\text { FSH } \\
(\mu \mathrm{g})\end{array}$ & $\begin{array}{l}\mathrm{LH} \\
(\mu \mathrm{g})\end{array}$ & $\begin{array}{l}\text { Progesterone } \\
\text { (ng/ml) }\end{array}$ & $\begin{array}{l}\text { Oestradiol } \\
(\mathrm{pg} / \mathrm{ml})\end{array}$ & & \\
\hline 1 & 50 ng agonist & $293 \pm 25^{\mathrm{b}}$ & $145 \pm 35$ & $15 \pm 2$ & $176 \pm 12$ & $14 \pm 2^{c}$ & $34 \pm 4$ & $128 \pm 11^{\mathrm{a}}$ & $328 \pm 26$ \\
\hline 2 & $500 \mathrm{ng}$ agonist & $592 \pm 160^{\mathrm{a}}$ & $123 \pm 35$ & $16 \pm 1$ & $182 \pm 21$ & $16 \pm 1^{\mathrm{c}}$ & $27 \pm 4^{a}$ & $140 \pm 8^{c}$ & $203 \pm 13^{b}$ \\
\hline 3 & $5000 \mathrm{ng}$ agonist & $911 \pm 134^{c}$ & $125 \pm 30$ & $19 \pm 1$ & $148 \pm 16^{a}$ & $9 \pm 1^{\mathrm{c}}$ & $29 \pm 3^{a}$ & $92 \pm 9$ & $143 \pm 2^{\mathrm{c}}$ \\
\hline 4 & LH-RH antibody & $204 \pm 20$ & $56 \pm 8^{b}$ & $21 \pm 2$ & $232 \pm 26$ & $19 \pm 4^{c}$ & $48 \pm 8$ & $52 \pm 4^{c}$ & $353 \pm 34$ \\
\hline 5 & $\begin{array}{l}\text { Control } \\
\text { (pro-oestrus) }\end{array}$ & $143 \pm 9^{c}$ & $57 \pm 7^{b}$ & $19 \pm 1$ & $218 \pm 10$ & $14 \pm 5^{a}$ & $107 \pm 10^{c}$ & $90 \pm 12$ & $621 \pm 58^{c}$ \\
\hline 6 & $\begin{array}{l}\text { Control } \\
\quad \text { (dioestrus) }\end{array}$ & $201 \pm 7$ & $111 \pm 17$ & $19 \pm 13$ & $205 \pm 21$ & $28 \pm 2$ & $43 \pm 5$ & $90 \pm 4$ & $313 \pm 23$ \\
\hline
\end{tabular}


without releasing the oocyte (Pl. 1, Fig. 4). These oocytes had not resumed meiosis, neither was there any mucification of the adjacent cumulus cells, suggesting that the follicles had not been exposed to a normal ovulatory stimulus despite the luteinization of the granulosa cells. Ovaries of rats in Groups 1-3 contained many lutein bodies some of which contained a structure which may have been the remnant of an oocyte that had undergone cytoplasmic cleavage (P1. 1, Fig. 4). These bodies differed therefore from the corpora lutea of the control ovaries, although they were similar in size and in cellular morphology and eosinophilia. There was no evidence of inhibition of follicular growth in Group 4 rats, although there were no corpora lutea in half of the animals; these ovaries did contain Graafian follicles with an abnormally enlarged antrum (cystic follicles) (P1. 1, Fig. 2).

\section{Circulating hormone concentrations}

Serum progesterone concentrations in rats in Groups 1-4 were significantly reduced when compared to those of dioestrous rats in Group 6 (Table 1). Serum oestradiol concentrations and uterine weight were lower in Groups 3 and 4 than in Group 6 rats (Table 1).

Pituitary content of FSH remained unaltered by either antibody or agonist treatment. Pituitary LH was lowered in Group 3 rats only. Serum LH was lowered in Group 4 rats relative to dioestrous controls but agonist treatment had no effect. Serum FSH was unaffected in Group 4 rats but was significantly raised in rats in Groups 1-3 (Table 1).

\section{Pituitary and ovarian $L H-R H$ receptor concentrations}

Pituitary LH-RH receptor concentrations at pro-oestrus (Group 5 rats) were significantly higher than at dioestrus 1 (Group 6). Values in Groups 1-4 did not differ significantly from that for dioestrous control rats from Group 6 (Text-fig. 1).

Ovarian LH-RH receptor concentrations showed no significant change between pro-oestrus and dioestrus and treatment with LH-RH agonist or LH-RH antibody did not alter the number of receptors (Text-fig. 1).

\section{Autoradiography}

Silver grains over pituitary tissue were unevenly distributed amongst cells of the adenohypophysis, being primarily localized over small groups of cells ( $\mathrm{Pl}$. 2, Figs 5 \& 6). The grains over ovarian tissue were distributed throughout thecal, granulosa and luteal tissue (Pl. 2, Figs 7\& 8). In both cases labelling in the control animals was obviously much less (data not shown).

\section{Discussion}

Hyperstimulation of the pituitary with daily injections of LH-RH agonist led to a cessation of normal oestrous cycles as shown by constant dioestrous smears and decreased serum progesterone and oestradiol levels indicative of impaired ovarian function. This agrees with the findings of

\section{PLATE 1}

Histological sections of rat ovaries.

Fig. 1. Control dioestrous animal. $\times 30$.

Fig. 2. LH-RH antiserum-treated rat showing abundance of follicles. $\times 30$.

Fig. 3. LH-RH agonist-treated rat showing predominance of luteal tissue. $\times 30$.

Fig. 4. LH-RH agonist-treated rat showing a trapped oocyte undergoing cleavage. $\times 200$. 
PLATE 1
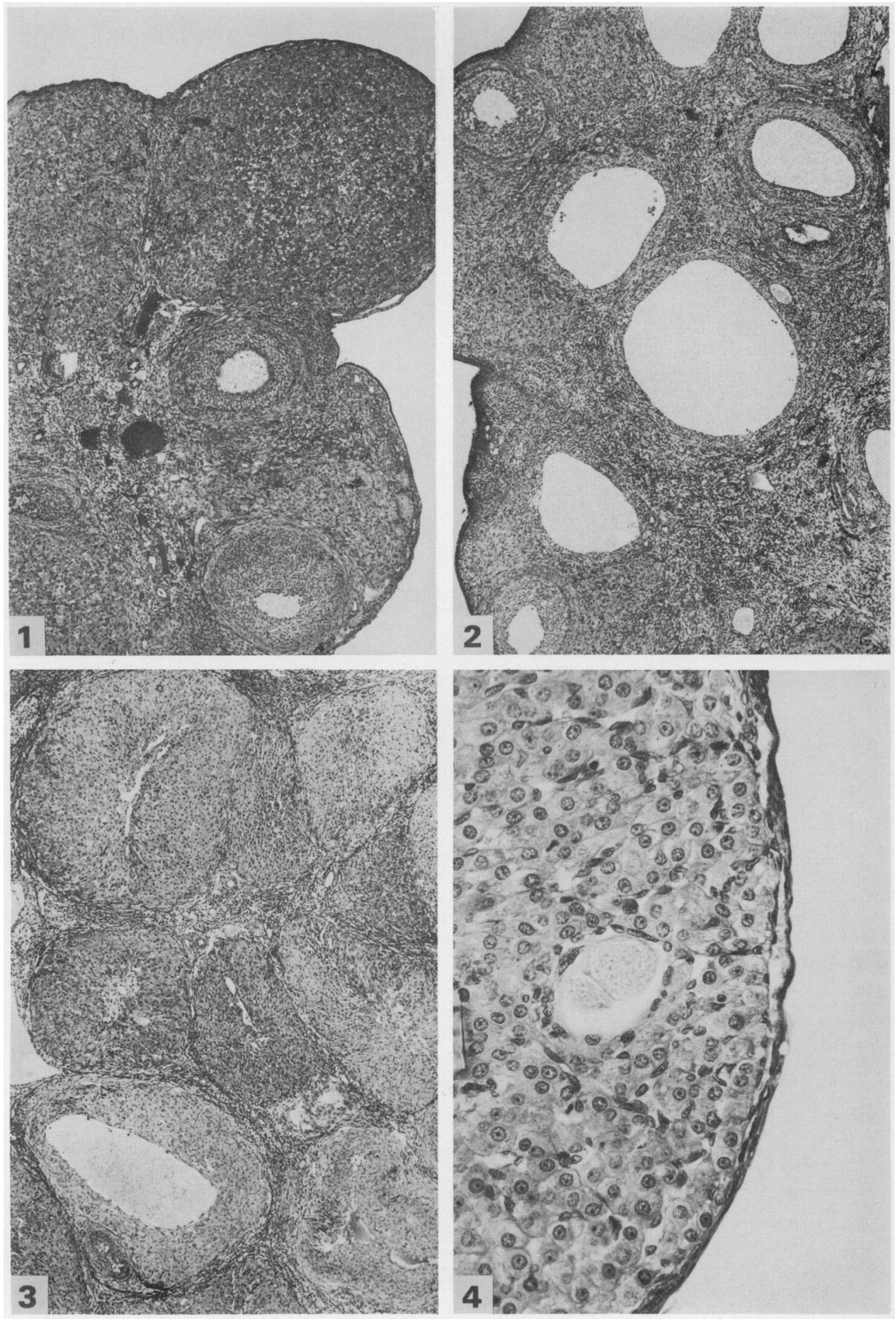

(Facing p. 248) 
PLATE 2
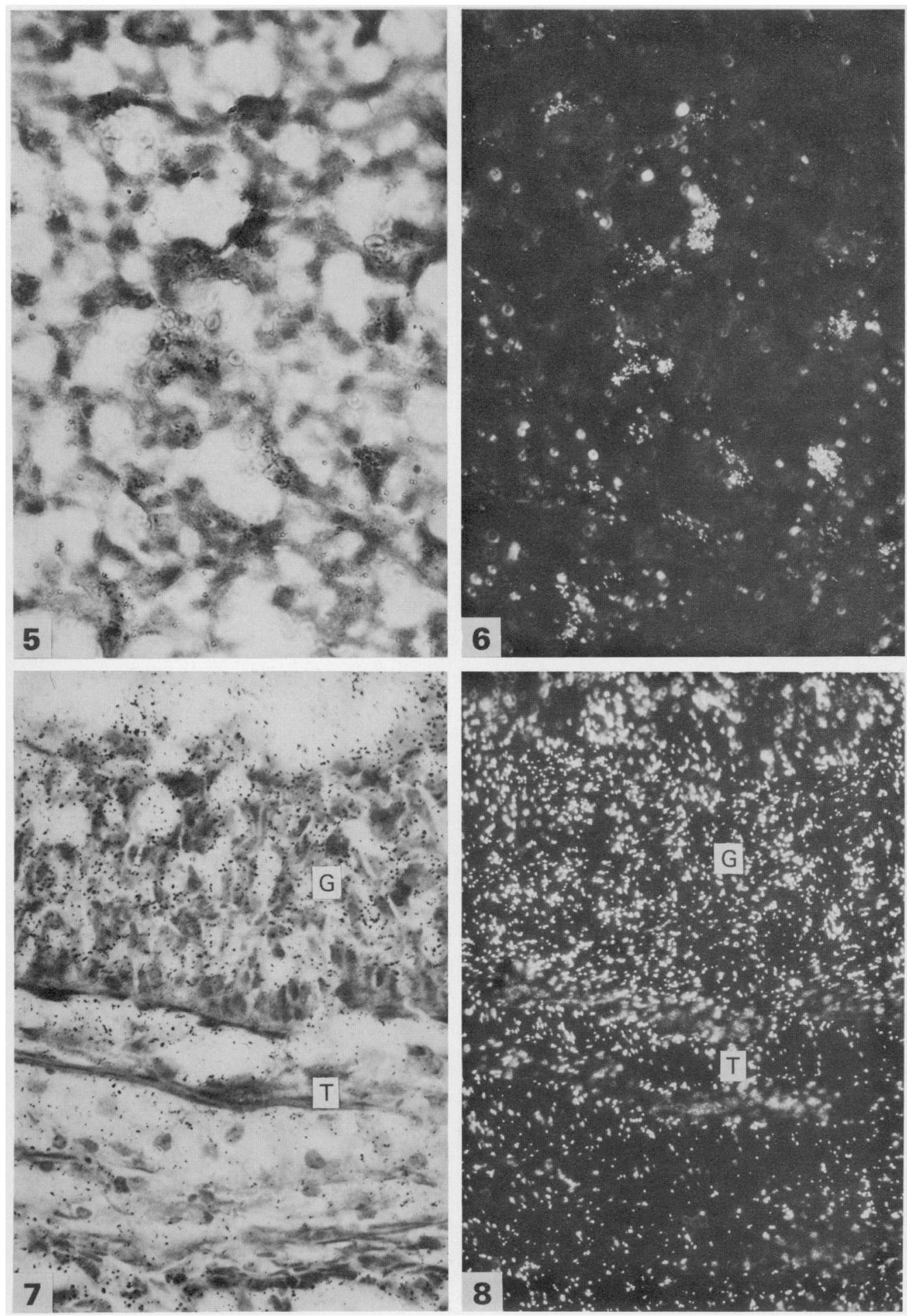

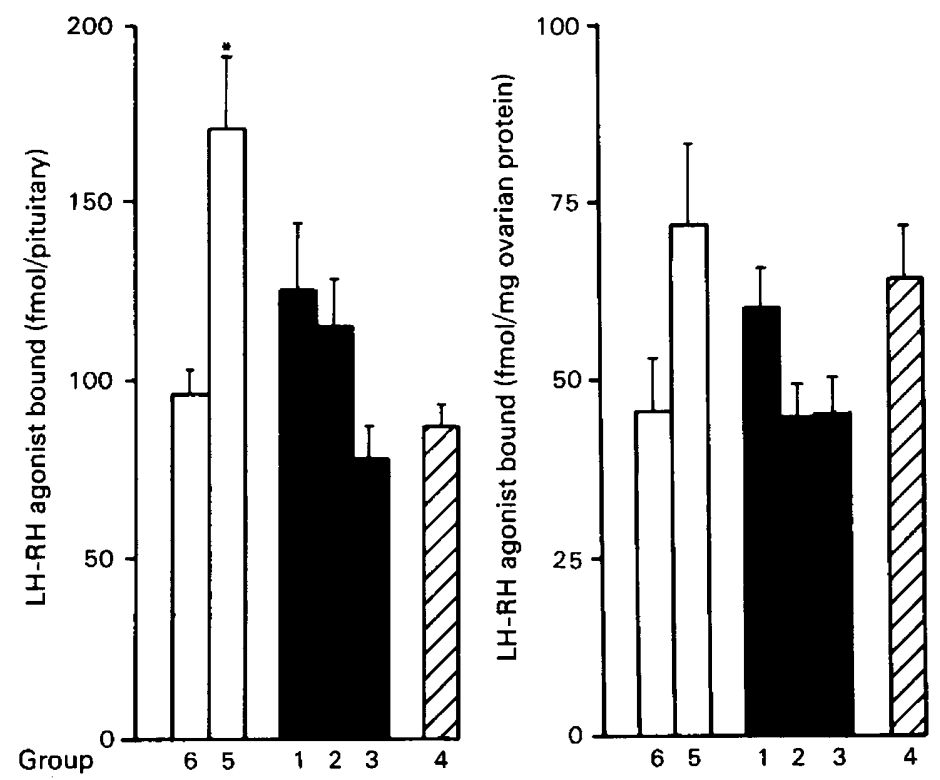

Text-fig. 1. Effect of daily injections of 50,500 or $5000 \mathrm{ng}$ LH-RH agonist ( times weekly injections of LH-RH antibodies (Group 4) on (a) pituitary and (b) ovarian LHRH receptors. Control animals received vehicle alone $(\square)$ and receptors were determined on the 1st day of dioestrus (Group 6) or pro-oestrus (Group 5). Values are mean \pm s.e.m. with 8 animals per group. ${ }^{*}$ Significantly different from value for Group $6(P<0 \cdot \overline{05}, t$ test $)$.

Johnson, Gendrich \& White (1976), Cusan et al. (1979) and Maynard \& Nicholson (1979). Agonist treatment resulted in multiple changes in ovarian morphology also indicative of impaired function: an inhibition of follicular growth (or an induction of atresia) and a predominance of lutein bodies, as has also been described by Sandow (1982). The absence of any associated progesterone rise despite abundant luteal tissue could be due to desensitization of the ovary after excessive gonadotrophin stimulation (Conti, Harwood, Hsueh, Dufau \& Catt, 1976) and/or to direct effects of LH-RH on the ovary, inhibiting, for example, progesterone production (Clayton, Harwood \& Catt, 1979). This concept of multiple direct LH-RH effects is also indicated by studies suggesting direct actions of LH-RH on granulosa cells (Hsueh \& Erickson, 1979), luteal cells (Clayton et al., 1979) and theca/interstitial cells (Magoffin, Reynolds \& Erickson, 1981; Popkin et al., 1983). This picture is corroborated by the autoradiographic data showing the presence of grains in most cell types within the ovary. Although our observations are based on only 2 animals they are in complete agreement with those of the study by Seguin, Pelletier, Dube \& Labrie (1982) and indicate that LHRH binds to, and therefore has the potential to exert effects at, multiple sites within the ovary.

Immunoneutralization of $\mathrm{LH}-\mathrm{RH}$ also led to a cessation of oestrous cycles and marked changes in ovarian morphology being consistent with an impaired ovulatory LH surge and resultant overmature and atretic follicles. Cystic follicles were also evident, similar to those seen in rats in persistent oestrus or when ovulation is blocked by pentobarbitone (Everett \& Sawyer, 1950; Braw \& Tsafriri, 1980) or after active immunization against LH-RH (Fraser \& Baker, 1978). These

\section{PLATE 2}

Figs 5-8. Autoradiographic localization of ${ }^{125}$ I-labelled LH-RH binding by light (Figs $5 \& 7$ ) and dark (Figs $6 \& 8$ ) field illumination in rat pituitary cells (Figs $5 \& 6$ ) and rat ovarian tissue (Figs $7 \& 8$ ) showing grains located over granulosa $(G)$ and thecal $(T)$ tissue. $\times 300$. 
structures are usually associated with increased progesterone production and may contribute to the serum progesterone concentrations after antibody treatment. Despite such marked changes in ovarian morphology with the agonist and antibody treatments, no change in the number of ovarian receptors was seen. This result may be explained by the fact that LH-RH binds to most cell types within the ovary and would therefore be unlikely to be affected by changes in relative abundance of specific tissue types. Pieper et al. (1981) reported that thrice daily injections of $6 \mu \mathrm{g} \mathrm{LH}-\mathrm{RH}$ into intact female rats failed to change the number of ovarian receptors, a finding that is consistent with our observations using LH-RH agonist. It is concluded, therefore, that ovarian LH-RH receptors are unlikely to be autoregulated.

Pituitary LH-RH receptors are, however, thought to be regulated by circulating gonadal hormones, prolactin and by LH-RH itself (see Clayton \& Catt, 1981, for review). A number of studies in male rats have revealed the complexity of elucidating the role of LH-RH receptor autoregulation in the intact animal. Acute exposure to LH-RH appears to result in an increase in pituitary LH-RH receptor numbers (Frager, Pieper, Tonetta, Duncan \& Marshall, 1981; Naess et $a l ., 1981)$ whereas chronic exposure did not result in an overall change in receptor concentrations (Heber, Dodson, Stoskopf, Peterson \& Swerdloff, 1982). In addition, LH-RH receptors responded biphasically with low doses of LH-RH increasing receptors and high doses reducing them (Clayton et al., 1981). The actions of LH-RH on its pituitary receptor numbers are clearly complex and involve consideration of duration of exposure as well as the dose. Intact female rats have rarely been studied, although Marchetti, Reeves, Pelletier \& Labrie (1982) injected cyclic rats with $200 \mathrm{ng}$ LH-RH agonist/day for 2 weeks and found pituitary receptor concentrations similar to those in untreated rats. Our results confirm and extend this finding, showing that chronic treatment of intact female rats with a range of doses of LH-RH (50, 500 or $5000 \mathrm{ng} \mathrm{LH-RH}$ agonist/day) results in pituitary LH-RH receptor concentrations within the range found in the cyclic animal.

Although we have not examined the possibility that the experimental regimes used may result in changes in the $K_{\mathrm{D}}$ of LH-RH receptors, this is considered unlikely. LH-RH receptor $K_{\mathrm{D}}$ appears to remain constant during the oestrous cycle (Clayton et al., 1980; Savoy-Moore et al., 1980) and during a variety of induced endocrine states (Marian et al., 1981) and indeed after a comparable study involving chronic LH-RH agonist administration (Marchetti et al., 1982).

Passive immunization of intact male rats with the same antiserum used in the present study resulted in a $25-35 \%$ reduction in pituitary LH-RH receptors (Clayton et al., 1982). The antibody does not have this effect in intact female rats, indicating that a fundamental difference may exist between the underlying mechanisms regulating pituitary LH-RH receptors in male and female rats.

Chronic LH-RH agonist or LH-RH antiserum administration resulted in altered ovarian steroid function. Since there is evidence that pituitary receptor numbers can be reduced by exogenous administration of gonadal steroids (Clayton \& Catt, 1981; Marchetti et al., 1982) it is likely that the continued presence of steroids, albeit at altered levels, prevents the expression of autoregulatory influences due to LH-RH alone. This can be seen in studies on gonadectomized animals in which exogenous administration of LH-RH results in marked decreases in the number of pituitary LH-RH receptors, and this phenomenon is reversed by steroid replacement therapy (Marchetti et al., 1982). In addition our data suggest that the altered serum hormone concentrations are within the physiological range found during the oestrous cycle, as seen by values for control dioestrous and pro-oestrous animals. We therefore suggest that, in the presence of near normal circulating concentrations of ovarian steroids and LH, pituitary LH-RH receptors are maintained, despite extremes of LH-RH stimulus, to concentrations within the range found in the normal cyclic animal.

In conclusion neither hypo- nor hyper-stimulation of the pituitary gonadotrophs or the ovary significantly alters the number of LH-RH receptors from the levels found during the normal rat oestrous cycle, indicating that in the female autoregulation of the LH-RH receptor is likely to be secondary to the influence of circulating hormones in the intact animal. 
We thank Dr J. Sandow for gifts of LH-RH agonist; Dr J. Uilenbroek and the NIAMDD, U.S.A., for gifts of materials for radioimmunoassay; and Mrs M. Swaney and Mr D. Doogan for technical assistance.

\section{References}

Backstrom, C.T., McNeilly, A.S., Leask, R.M. \& Baird, D.T. (1982) Pulsatile secretion of LH, FSH, prolactin, oestradiol and progesterone during the human menstrual cycle. Clin. Endocr. 17, 29-42.

Braw, R.H. \& Tsafriri, A. (1980) Effect of PMSG on follicular atresia in the immature rat ovary. $J$. Reprod. Fert. 59, 267-272.

Clark, M.R. (1982) Stimulation of progesterone and prostaglandin accumulation by luteinizing hormone releasing hormone (LHRH) and LHRH analogs in rat granulosa cells. Endocrinology 110, 146-151.

Clayton, R.N. \& Catt, K.J. (1981) Gonadotropinreleasing hormone receptors : characterization, physiological regulation and relationship to reproductive function. Endocr. Rev. 2, 186-209.

Clayton, R.N., Harwood, J.P. \& Catt, K.J. (1979) Gonadotrophin-releasing hormone analogue binds to luteal cells and inhibits progesterone production. Nature, Lond. 282, 90-92.

Clayton, R.N., Solano, A.R., Garcia-Vela, A., Dufau, M.L. \& Catt, K.J. (1980) Regulation of pituitary receptors for gonadotropin-releasing hormone during the rat estrus cycle. Endocrinology 107, 699-706.

Clayton, R.N., Popkin, R.M. \& Fraser, H.M. (1982) Hypothalamic regulation of pituitary gonadotropinreleasing hormone receptors: effects of gonadotropin releasing hormone immunoneutralization. Endocrinology 110, 1116-1123.

Conti, M., Harwood, J.P., Hsueh, A.J.W., Dufau, M.L. \& Catt, K.J. (1976) Gonadotropin-induced loss of hormone receptors and desensitization of adenylate cyclase in the ovary. J. biol. Chem. 251, 7729-7731.

Corbin, A. \& Bex, F.J. (1981) Luteinizing hormone releasing hormone agonists induce ovulation in hypophysectomized rats: direct ovarian effect. Life Sci. 29, 185-192.

Cusan, L., Auclair, C., Belanger, A., Ferland, L., Kelly, P.A., Seguin, C. \& Labrie, F. (1979) Inhibitory effects of long term treatment with a luteinizing hormonereleasing hormone agonist on the pituitary-gonadal axis in male and female rats. Endocrinology 104, 1369-1376.

de Jong, F.H. \& Sharpe, R.M. (1977) The onset and establishment of spermatogenesis in rats in relation to gonadotrophin and testosterone levels. $J$. Endocr. 75, 197-207.

Ekholm, C., Hillensjö, T. \& Isaksson, O. (1981) Gonadotropin releasing hormone agonists stimulate oocyte meiosis and ovulation in hypophysectomized rats. Endocrinology 108, 2022-2024.

Everett, J.W. \& Sawyer, C.H. (1950) A 24-hour periodicity in the "LH-release apparatus" of female rats, disclosed by barbiturate sedation. Endocrinology 47, $198-218$.
Frager, M.S., Pieper, D.R., Tonetta, S.A., Duncan, J.A. \& Marshall, J.C. (1981) Pituitary gonadotropin-releasing hormone receptors. J. clin. Invest. 67, 615-623.

Fraser, H.M. \& Baker, T.G. (1978) Changes in the ovaries of rats after immunization against luteinizing hormone-releasing hormone. J. Endocr. 77, 85-93.

Fraser, H.M. \& Sandow, J. (1977) Gonadotrophin release by a highly active analogue of luteinizing hormonereleasing hormone in rats immunized against luteinizing hormone-releasing hormone. J. Endocr. 74, 291-296.

Fraser, H.M., Popkin, R.M., McNeilly, A.S. \& Sharpe, R.M. (1982) Changes in pituitary LHRH receptor levels in situations of increased or decreased gonadotrophin secretion in the male rat. Molec. cell. Endocr. 28, 321-333.

Heber, D., Dodson, R., Stoskopf, C., Peterson, M. \& Swerdloff, R.S. (1982) Pituitary desensitization and the regulation of pituitary gonadotropin-releasing hormone $(\mathrm{GnRH})$ receptors following chronic administration of a superactive $\mathrm{GnRH}$ analog and testosterone. Life Sci. 30, 2301-2308.

Hsueh, A.J.W. \& Erickson, G.F. (1979) Extrapituitary action of gonadotropin-releasing hormone: direct inhibition of ovarian steroidogenesis. Science, $N, Y$. 204, 854-855.

Johnson, E.S., Gendrich, R.L. \& White, W.F. (1976) Delay of puberty and inhibition of reproductive processes in the rat by a gonadotropin-releasing hormone agonist analog. Fert. Steril. 27, 853-860.

Lowry, O.H., Rosebrough, N.J., Farr, A.L. \& Randall, R.J. (1951) Protein measurements with the folin phenol reagent. J. biol. Chem. 193, 265-275.

Magoffin, D.A., Reynolds, D.S. \& Erickson, G.F. (1981) Direct inhibitory effect of GnRH on androgen secretion by ovarian interstitial cells. Endocrinology 109, 661-663.

Marchetti, B., Reeves, J.J., Pelletier, G. \& Labrie, F. (1982) Modulation of pituitary luteinizing hormone releasing hormone receptors by sex steroids and luteinizing hormone releasing hormone in the rat. Biol. Reprod. 27, 133-145.

Marian, J., Cooper, R.L. \& Conn, M.P. (1981) Regulation of the rat pituitary gonadotropin-releasing hormone receptor. Molec. Pharm. 19, 399 405.

Maynard, P.V. \& Nicholson, R.I. (1979) Effects of high doses of a series of new luteinizing hormone releasing hormone analogues in intact female rats. $\mathrm{Br} . \mathrm{J}$. Cancer 39, 274-279.

Meidan, R. \& Koch, K. (1981) Variations in luteinizing hormone-releasing hormone receptors in pituitary cells from immature and mature cycling female rats. FEBS Letters 132, 114-116. 
Naess, O., Cusan, L., Brekke, I., Purvis, K., Torjesen, P. \& Hansson, V. (1981) Effects of castration, sex steroids, LHRH and glucocorticoids on LHRH binding in the anterior pituitary of male rats. Int. J. Androl. 4, 685-690.

Park, K.R., Saxena, B.B. \& Gandy, H.U. (1976) Specific binding of LHRH to the anterior pituitary gland during the oestrous cycle in the rat. Acta endocr., Copenh. 82, 62-70.

Pieper, D.R., Richards, J.S. \& Marshall, J.C. (1981) Ovarian gonadotropin-releasing hormone (GnRH) receptors: characterization, distribution and induction by GnRH. Endocrinology 108, 1148-1155.

Popkin, R., Fraser, H.M. \& Jonassen, J. (1983) Stimulation of androstenedione and progesterone release by LHRH and LHRH agonist from isolated rat preovulatory follicles. Molec. cell. Endocr. 29, 169-181.

Reeves, J.J., Tarnavsky, G.K. \& Platt, T. (1982) Pituitary and ovarian luteinizing hormone releasing hormone receptors during the estrous cycle, pregnancy and lactation in the rat. Biol. Reprod. 27, 316-319.

Sandow, J. (1982) Gonadotropin and antigonadotropic actions of LH-RH analogues. In Neuroendocrine Perspectives, vol. 1, pp. 339-395. Eds E. E. Muller \& R. M. MacLeod. Elsevier Biomedical Press, A:ssterdam.

Savoy-Moore, R.T., Schwartz, N.B., Duncan, J.A. \& Marshall, J.C. (1980) Pituitary gonadotropin-releasing hormone receptors during the rat estrous cycle. Science, N.Y. 209, 942-944.

Scaramuzzi, R.J., Corker, C.S., Young, G. \& Baird, D.T. (1975) Production of antisera to steroid hormones in sheep. In Steroid Immunoassay, pp. 111-122. Eds E. H. D. Cameron, S. G. Hillier \& K. Griffiths. Alpha Omega Alpha, Cardiff.

Seguin, C., Pelletier, G., Dube, D. \& Labrie, F. (1982) Distribution of luteinizing hormone-releasing hormone receptors in the rat ovary. Regulatory Peptides 4, 183-190.

Tarnavsky, G.K. \& Platt, T. (1982) Pituitary and ovarian luteinizing hormone releasing hormone receptors during the estrous cycle, pregnancy and lactation in the rat. Biol. Reprod. 27, 316-319.

Received 11 February 1983 